\title{
Lineament Analysis of Morphostructures of the Uchur-Maya Basin (Southeastern Siberian Platform) from SRTM Data: Relationship with Metallogeny
}

\author{
Gul'shat Z. Gil'manova, Mikhail V. Goroshko, Oleg V. Rybas, Alexei N. Didenko \\ Institute of Tectonics and Geophysics, Far East Branch, Russian Academy of Sciences, Khabarovsk, Russia \\ Email: gigulya@yandex.ru
}

Received September 25, 2012; revised October 22, 2012; accepted November 11, 2012

\begin{abstract}
Based on digital elevation models SRTM03 and SRTM30_Plus (Shuttle Radar Topography Mission Survey) the technique for detecting major structural elements and elucidating details of the geologic structure including discrimination of linear structures and texture features is elaborated. The computation of the modulus of the first derivative by the coordinate, i.e., the modulus of the topography gradient, characterizing the state of the surface by steepness and direction of slope (azimuth) is assumed as a basis. The technique was applied for the study of tectonics and metallogeny of the Uchur-Maya Meso-Neoproterozoic basin. The structural and lithological controlling factors of ore occurrences are established. It has been shown the efficacy of using the transformed digital elevation models for the geological and tectonic studies.
\end{abstract}

Keywords: Space SRTM Survey; Lineaments; The Uchur-Maya Basin; Metallogeny

\section{Introduction}

Meso-Neoproterozoic and Early Paleozoic deposits of the Precambrian platform covers draw much attention, in the first place, because of their high mineragenic potential. The discovery of major and unique uranium, nickel, cobalt, copper, polymetallic and oil and gas deposits is clear evidence. Such deposits are known to be explored on the Australian, South African, North American and North China platforms. Poorly studied eastern Siberian platform areas, where non-estimated uranium, copper, polymetallic, molybdenum, gold, vanadium deposits and numerous ore occurrences have been found, have great exploration prospects for super major deposits.

Presently, the satellite images and the results of digital elevation model processing are widely used to study the geologic structure, tectonics and peculiarities of localization of ore deposits. Topography, considered one of the main evidences of geodynamic processes developing in the Earth's subsurface layers, reflects the geologic structure of the area. The lineament network and different size concentric structures, often structurally and tectonically controlling the spatial distribution of melts and solutions and the associated mineralization at different depths, are suggested to be one of the manifestations of the above processes.

In this connection, we believe that distant space-based techniques providing detection of the leading types of ore-controlling structures for different scale level investigations contribute significantly to the establishment of metallogenic features of the regions, still poorly studied by land-based methods, including the eastern margin of the Siberian platform. The paper deals with digital elevation models [1], to which a specialized processing technique has been applied. It involves the detection of linear structures based on the computation of the modulus of the first derivative by the coordinate - the modulus of the topography gradient, characterizing the state of the surface by steepness $[1,2]$. The WinLessa program technique has also been applied for the detection of lineaments [3].

The object of our investigations is the Uchur-Maya Meso-Neoproterozoic sedimentary basin (Figure 1(a)) located in the southeastern Siberian platform in the Uchur, Maya, Aldan and Amga River basins in the northern areas of the Khabarovsk Territory and the southeast of the Sakha Republic (Yakutia). The authors have analyzed the materials on stratigraphy, magmatism, tectonics and the deep structure of the basin area. This allowed detection and description of characteristics of the main sedimentary and magmatic rock complexes and implementation of the joint analysis of distribution of ore deposits and occurrences, on the one hand, and of tectonic faulting, on the other hand. 


\section{A Brief Description of the Geologic Structure of the Study Area}

The Uchur-Maya basin (depression), covering a large area of about $200,000 \mathrm{~km}^{2}$, represents a continuously evolving depression structure (Figures 1(b) and (c)). The basin has a complicated block structure; in terms of paleontology, its stratigraphic section is one of the most complete and well described Upper Proterozoic reference sections in North Eurasia [4-9].

\subsection{Stratigraphy}

The basin formed on the peneplenized granite-gneiss basement of the platform at the beginning of the Mesoproterozoic about $1650 \mathrm{Ma}$ ago, having been filled with the sedimentary rocks for more than one billion years. The pre-plate and plate rock complexes are discriminated in its composition. The pre-plate complexes are completely built up of weakly dislocated Meso-Neoproterozoic rocks, whereas the plate complexes are composed of horizontally occurring Upper Neoproterozoic (Ediacaran)-Silurian and Mesozoic rocks. There have been distinguished six Meso-Neoproterozoic pre-plate complexes, including the Mesoproterozoic (Uya, Uchur, Aimchan and Kerpyl) and Neoproterozoic (Lakhanda and Uya) ones separated from one another by breaks in occurrence and unconformities and marking the most important stages of sedimentation.

1) The Uya and Uchur complexes formed 1650 - 1400 Ma ago (Calymmian). The Uya complex with an angular unconformity occurs on the crystalline basement rocks and Paleoproterozoic felsic effusive rocks, being separated from either of these rocks by $40 \mathrm{~m}$ thick weathering crust. The total thickness of the deposits ranges from 500 to $1500 \mathrm{~m}$. They are comprised of red conglomerates and sandstones with flow units of almond-shaped sub-alkali olivine basalts and leucobasalts. The rocks of the Uchur complex are unconformably overlying the Uya complex deposits. In the lower part of the section of the series, a specific feature of rocks is displayed in an intense red color, approximately similar relationship between sandstones (55\%) and silt sandstones and siltstones (40\%), under sharply subordinated carbonate rock amount $(5 \%)$. The total thickness of the Uchur complex varies from 970 to $2700 \mathrm{~m}$;

2) The Aimchan complex, a large sedimentary transgressive rhythm, .originated 1400 - $1200 \mathrm{Ma}$ ago (Ectasian). In the basal horizons of the complex, light green, intermediate- and coarse-grained quartz, sometimes weakly glauconitic sandstones containing lenses of quartz gravelites and iron sand layers occur, whereas in the upper part of the complex the siltstone interlayers are deposited. Overlying are dark siltstones, quartz and quartz-feldspar sandstones, rarely mudstones. At the surface of rock stratification, the shrinkage cracks and ripple marks are seen in abundance. The deposit thickness is increasing from 150 to $2000 \mathrm{~m}$ from west to east;

3) The Kerpyl complex, to 1350 - $1700 \mathrm{~m}$ thick, formed 1200 - $1000 \mathrm{Ma}$ ago (Stenian). $\mathrm{Pb}-\mathrm{Pb}$ age of limestones of the Malginskaya Suite (the middle part of the Kerpyl series) is $1043 \pm 14 \mathrm{Ma}$ [10]. A significant break in sedimentation is established between Stenian deposits and overlying Tonian rocks, the development of the weathering crust to $0.5 \mathrm{~m}$ thick is evidence. According to $\mathrm{Pb}-\mathrm{Pb}$ method, the age of this boundary is estimated to be $1025 \pm 40 \mathrm{Ma}[11]$;

4) The Lakhanda complex, to $500-850 \mathrm{~m}$ thick with an eastward increase, originated 1000 - $850 \mathrm{Ma}$ ago (Tonian). The complex is divided into two parts: the lower silica carbonate-clastic and the upper significantly carbonate. The limestones and dolomites of the upper part accumulated in the tidal zone. The age of baddeleyite from sill of basic rocks, intruded into the upper horizons of the Lakhanda complex, is $974 \pm 7 \mathrm{Ma}$ [12]. In compliance with the Materials of Interdepartmental Stratigraphic Committee (ISC) of Russia, the boundary between the Kerpyl and Lakhanda complexes is about 1030 Ma. According to the Russian General Stratigraphic Scale of Precambrian, it is just the age determination value which is assumed to identify the isotopic age of the Upper Riphean (Neoproterozoic) lower boundary [13];

5) The Uya complex corresponds to the Cryogenian $(850-635 \mathrm{Ma})$ in accordance with the regional stratigraphic scheme. Its thickness is eastwardly increasing from 400 to $4500 \mathrm{~m}$. The rocks of the series are predominantly clastic; the prevalence of siltstone component over the clayey one is increasing toward the top of the rock series. There exist some problems as to the absolute age determination of the Uya complex. The age of baddeleyite from sill of basic rocks, intruded into the lower horizons of the complex (the Kandykskaya Suite), attains to $1005 \pm 4 \mathrm{Ma}$ [12] and is considered as the upper age limit for the entire series. Based on other isotopic data, the age of the complex is significantly younger: 1) $\mathrm{Rb}-\mathrm{Sr}$ age of mudstones from the middle part of the section is $730 \pm 80 \mathrm{Ma}$ [14]; 2) $\mathrm{K}-\mathrm{Ar}$ age of the deposits from the lower part of the Uya series reaches $\sim 760 \mathrm{Ma}[4$, $15]$

6) Ediacaran deposits of the region are discriminated as the Yudoma complex of mudstones, dolomites, dolomitic limestones and siltstones of 100 to $900 \mathrm{~m}$ thickness. The bottom of the Yudoma complex is dated $645 \mathrm{Ma}$ [16] and $639 \pm 20 \mathrm{Ma}$ [17], whereas the top is dated $553 \pm 23$ Ma [17];

7) Cambrian deposits, 50 to $215 \mathrm{~m}$ thick, are represented by color limestones and dolomites, clayey bituminous limestones alternating with siliceous limestones and mergels. The rocks of the Ediacaran-Cambrian struc- 

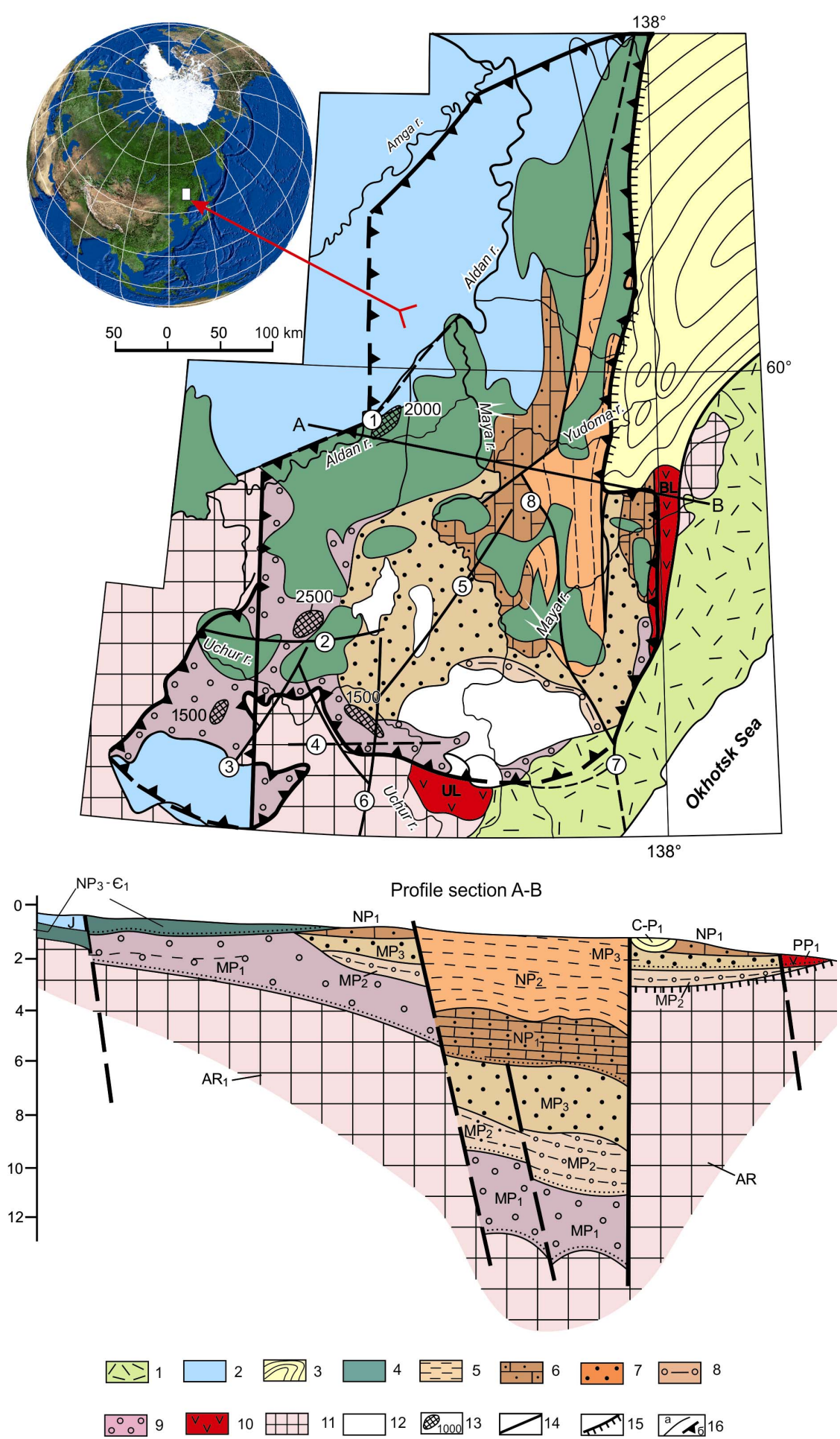

Figure 1. Location (a), geological sketch-map (b) and profile section (c) of the Uchur-Maya basin. Explanations to 1(b) and (c): 1: Cretaceous oversubduction volcano-plutonic belt; 2: Jurassic deposits; 3: Late Paleozoic Verkhoyan-Kolyma orogenic belt; 4 - 9: Mesoproterozoic-Cambrian deposits of the Uchur-Maya basin: 4: Ediacaran-Cambrian plate complex; 5: Cryogenian deposits (Uya series); 6: Tonian deposits (Lakhanda series); 7: Stenian deposits (Kerpyl series); 8: Ectasian deposits (Aimchan series); 9: Calymmian deposits (Uchur and Uya series); 10: Late Paleoproterozoic volcano-plutonic Bilyakchan-Ulkan belt (BL: Bilyakchan, UL: Ulkan); 11 and 12: Archean-Proterozoic metamorphic rocks; 11: in autochtonous; 12: allochtonous occurrences; 13: the basement depth from geophysical data; 14 and 15: major steeply-dipping faults and thrust-faults, respectively (numbers in the circles: 1: Legden, 2: Ket-Kap, 3: Aim-Tokin, 4: Toluk, 5: Uchur-Maya, 6: Uya, 7: Bilyakchan, 8: Nel'kan); 16: geological boundaries, including those of the Uchur-Maya basin (16b). 
tural stage form wide gentle troughs (mulde type) and narrow fault-related synclinal folds.

\subsection{The Main Tectonic Features}

The rocks of the Meso-Neoproterozoic basin have very insignificant dip angles. The generally undisturbed occurrence of the cover is disturbed only in individual segments, which is usually related to fault tectonics, whereas in the interfluve of the Great Aim and Uchur Rivers it is due to the Mesozoic granitoid intrusions. Our geological-geophysical data for the southern part of the Uchur-Maya depression [8] are proof of persistent $3^{\circ} \mathrm{N}$ $9^{\circ} \mathrm{E}$ direction of the basement submergence and increasing thickness of Mesoproterozoic deposits in the same direction. In the southeasternmost part of the UchurMaya depression, Meso-Neoproterozoic deposits are crumpled into a range of linearly extended submeridional synclinal and anticlinal folds with gentle dips of the wings. Folding was most likely caused by the collision processes occurring in the Okhotsk and East Aldan terrane junction zone in the Late Paleozoic and Mesozoic.

In the basement relief, deep (down to $6 \mathrm{~km}$ ) Aldan and Uchur-Maya troughs with the separating Dygda sublatitudinal line type lifting are discriminated (Figure 1(b)). From the geological survey data, the line type lifting is northeasterly traced for $200 \mathrm{~km}$ at $50-75 \mathrm{~km}$ width. The uplifts included in the Dygda dislocation system have steeper dips of the wings; they are more eroded in the dome parts and are disturbed by several major faults.

The most prominent structural element of the UchurMaya depression is the Yudoma-Maya aulacogen located in the eastern part of the depression and represented as a linear graben meridionally extended for $700 \mathrm{~km}$ at 40 -
$100 \mathrm{~km}$ width. According to the geophysical data, the maximum depth of the crystalline basement occurrence exceeds $12 \mathrm{~km}$ (Figure 1(c)).

Based on the contemporary concepts, starting from the Early Precambrian, the Siberian Craton was a part of the gigantic supercontinent Columbia [18,19]. The latter included also North America, Europe, South and North China, Australia, Antarctica and other continents. The analyzed paleomagnetic data [9] for the Paleo-, Mesoand Neoproterozoic show that Siberia was located in the near-equatorial latitudes in the Meso-Neoproterozoic (Figure 2).

For $1500 \mathrm{Ma}$, the K. Condie reconstruction was taken as a basis [19], where the Greenland-Canada margin of Laurentia, the Aldan-Baikal margin of Siberia and the northern margin of the Sino Korean Craton form a single sedimentary basin. Using paleomagnetic data we "tiedup" this reconstruction to the latitudinal coordinates. The largest fragment of the supposed Paleoproterozoic supercontinent comprises Laurentia, Siberia, Baltica, North Australia and North China (Figure 2(a)).

In the Early Neoproterozoic (950 - $900 \mathrm{Ma}$; Figure 2(b)) Siberia occupied the southern tropical $0^{\circ}-20^{\circ}$ latitudes and turned westward its Baikal margin [9]. At the beginning of the Cryogenian (850 - $800 \mathrm{Ma})$ it displaced $20^{\circ} \mathrm{N}$ and, which is of significance, rotated almost $90^{\circ}$ clockwise, i.e., the Baikal margin turned northward. In the middle of the Cryogenian (750 - $700 \mathrm{Ma})$ Siberia displaced $5^{\circ} \mathrm{S}-10^{\circ} \mathrm{S}$ and, practically, did not change its spatial orientation, whereas by the end of the Cryogenian (650 $600 \mathrm{Ma}$ ) it further displaced $15^{\circ} \mathrm{S}-20^{\circ} \mathrm{S}$ retaining almost the same orientation. By the end of the Varanger-the beginning of the Ediacaran (570 - $550 \mathrm{Ma}$; Figure 2(c)),

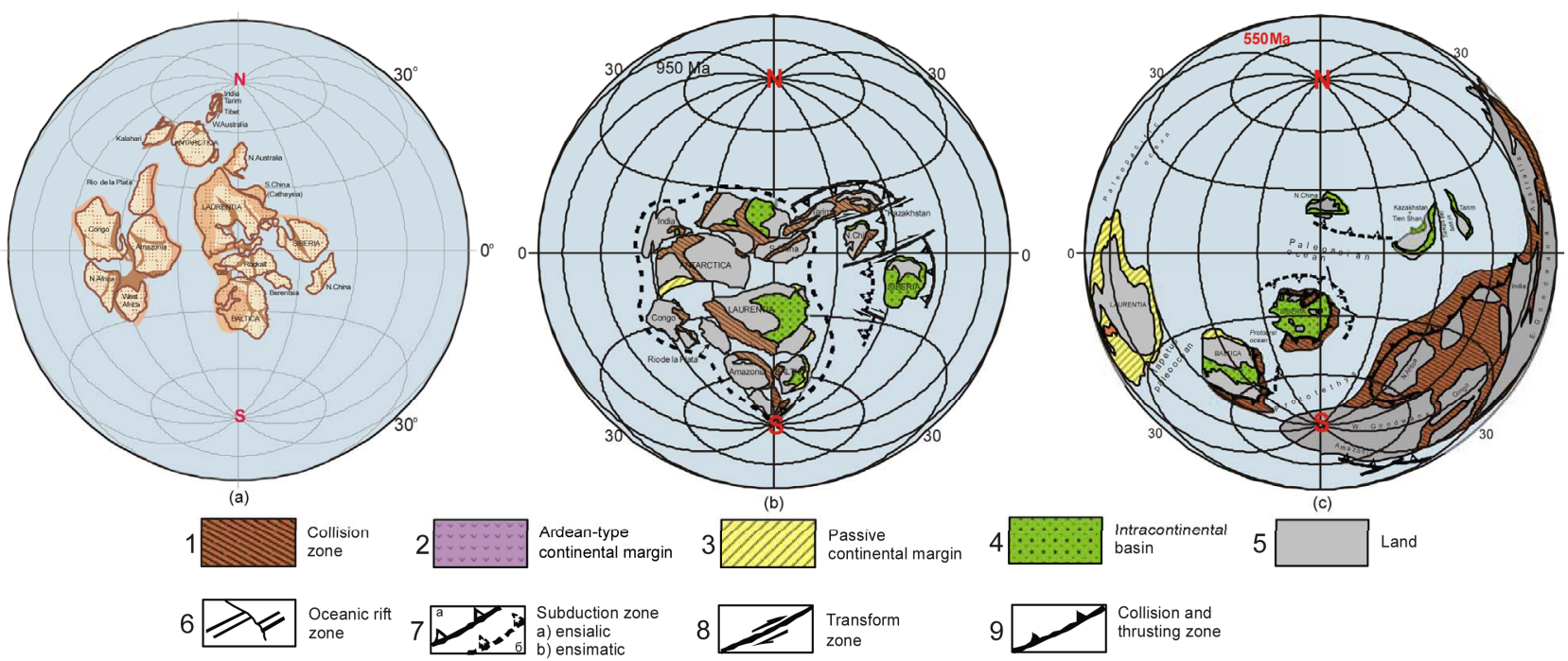

Figure 2. Paleoreconstructions for 1500 (a), 950 (b) and 550 (c) Ma. A: block composition by K. Condie (2002), paleolatitudinal position and azimuthal orientation for Laurentia by Pesonen et al. [26] and Li et al. [27], and for Siberia by Ernst et al. [28]. B, C: according to [29] with changes. 
Siberia displaced even farther $20^{\circ} \mathrm{S}-25^{\circ} \mathrm{S}$ (the Taimyr margin is located at $40^{\circ} \mathrm{S}$ latitude) and rotated $10^{\circ}-15^{\circ}$ anticlockwise [9].

The deposits of the Uchur-Maya basin were formed by Meso-Neoproterozoic and Cambrian sedimentary layers to $12 \mathrm{~km}$ thick. They were predominantly deposited in the vast shallow warm and continuously existing sea.

\section{Relationship of Ore Deposits with Fault Tectonics of the Uchur-Maya Basin}

The digital elevation models SRTM03 and SRTM30 [http://www2.jpl.nasa.gov/srtm/cbanddataproducts.html] were considered to be the basic materials for investigation and processing. Using the original programs and ArcGis 9.3, and, also, the data on metallogeny of the study area, processing and further visualization of images were carried out.

\subsection{Processing Technique for Digital Elevation Models}

A raster digital elevation model is presented as a $3 \mathrm{D}$ object in the coordinate system of a raster image $(x, y)$, and values in each point $f(x, y)$ are numerical values of real elevations of the topography above sea-level in meters.

The technique developed for detection of the topography structures using digital elevation models is based on application of the scale-space theory [20-22], whose basic proposition suggests applying the Gaussian function as the operator of the convolution kernel for the signal studied. The geometrical sense of the convolution of the surface $f(x, y)$ with the Gaussian kernel is smoothing of the surface topography with a specific scale parameter $t$. The value $t$ is related to the result from the convolution operation $L(x, y, t)$ so that all the details whose linear sizes do not exceed $\sqrt{t}$ values, are discarded from the initial image, i.e., the term "scale" should be understood in the context of precision of the data presented. On the one hand, this provides eliminating noise from the initial data (or, although permits its significant weakening); on the other hand, this allows performing the initial data generalization, i.e., using the topography elements of linear dimensionality necessary at the current processing stage.

Using the multiscale presentation is needed, because there does not exist such a universal scale for real objects which would allow discriminating all structural elements during the only one transformation series. Most often, the subtle and precise features are better displayed at low values of the smoothing scale parameter $t$, whereas the rough forms are failing. At increasing $t$, generalization of the processed surface $f(x, y)$ takes place with failure of details, but the possibility appears for the manifestation of rougher regional structural components. Thus, during a series of procedures for processing the surface $f(x, y)$ (these may be the modulus of gradient, the Laplacian of the Gaussian surface or any other transformation) at different levels of generalization, a series of results will be obtained, which, in turn, may be used for further processing in the analytical systems. For example, when discriminating lineaments from the modulus of gradient of the fixed smoothing scale parameter $t$, it is possible for us to be aware of the characteristics necessary and to filter those unnecessary at the given stage of processing the objects. Having performed these procedures for each of the generalization levels, at the last stage, we can unify all the discriminated lineaments to obtain a general pattern.

\subsection{Discriminating the Topography Structure}

As for the geomorphological studies, the objective is reduced to identifying the linear, ring structures, and, as an independent object, the textures with clearly manifested morphometric indications (sedimentary basins, mountain massifs, etc.), which can be the subject of further automatic processing and visual estimation as well.

The modulus of gradient (hereafter MGR) is the most effective instrument for detecting linear structures, because spatially extended segments with close gradient values are virtually present in fault zones. Besides, the MGR value is close to zero at any extremum point, which, as a result, allows detection of plains and ranges as linearly extended objects.

In order to reveal major structural elements and elucidate the details of the geologic structure of the study area, the images obtained during the digital elevation model processing by MGR at values $t=1,16,64$ were used.

The applied procedures of the digital elevation model processing by MGR are visually increasing a degree of indentation of the topography (Figure 3). In the transformed image, this characteristic is demonstrated by different tones of grey. The less indented segments (blocks) are colored black and dark-grey, the most indented ones are shown in different tones of grey and light-grey. One can consider textures as an independent object, i.e., zones with clearly manifested morphometric indications (sedimentary basins, mountain massifs, built up of different intrusive, sedimentary and effusive rocks, etc.) are discriminated as a result of processing.

The texture peculiarities may serve as an indicator of rock composition and major lithological and petrographic complexes. The character of the boundaries between different types of the topography testifies to the interrelationship between different strata, indicating whether the contact is normal stratigraphic or tectonic one.

Stripe linear anomalies are commonly identified with linear bodies (dikes) of intrusive rocks, stable to weather- 


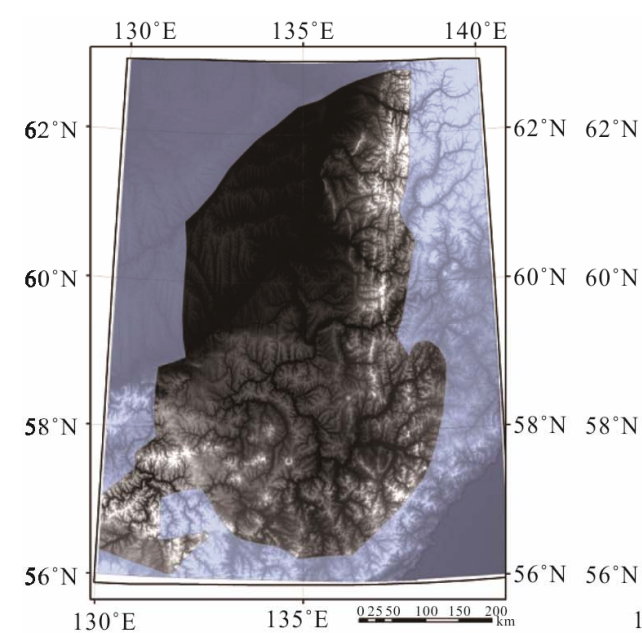

(a)

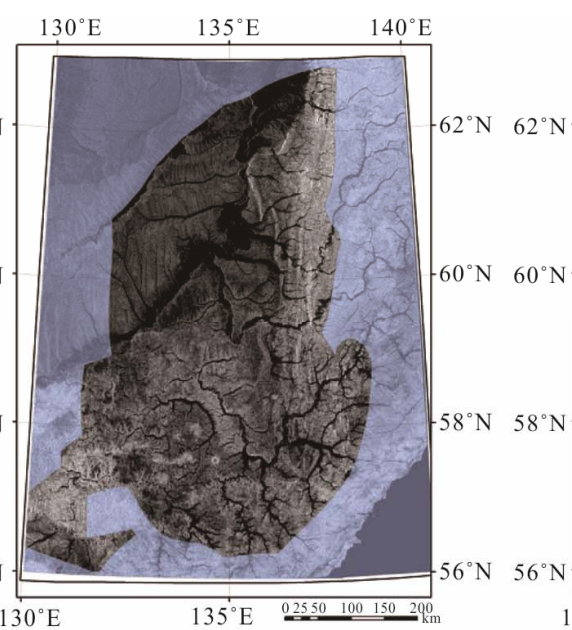

(b)

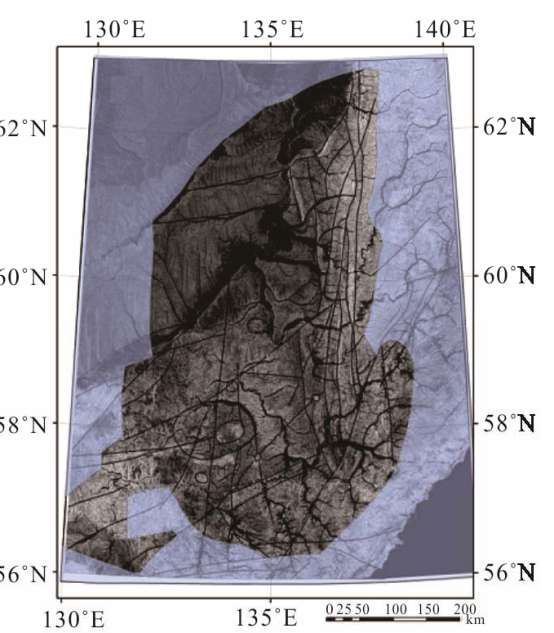

(c)

Figure 3. Basic digital elevation model of the Uchur-Maya basin (A) and examples of its processing (B, C).

ing, with steeply dipping strata of deposits and differently oriented faults. The ring anomalies correspond to small size intrusions, volcano-tectonic depressions and intrusive-dome structures. The elements of the hydrological network allow detecting the most prominent regional geological objects including faults and folded structures.

Further image processing was carried out applying the program technique LESSA (Lineament Extraction and Stripe Statistical Analysis), implemented in the program WinLESSA [3]. The program provides the uniform numerical description of images showing different type schemes and digital elevation models, the detection of linear elements of the pattern and description of their properties in a way common for the geological studies. In the search for the linear elements, the rectified segments of the boundaries of areas differing in brightness have been distinguished in a halftone image. During the computation, the size of elementary linear elements is given with an account of the initial image resolution, the geological features of the study area and the objectives set. The analysis of the data obtained during the computation provides the distribution of locally dominating orientations over the study area, the uniform and anomalous areas in terms of orientation properties, etc.

As a final result, the following maps have been done for the study area: those of lineaments exhibiting different degree of their manifestation, rose-charts of lineament orientation over the study area, boundaries of changing pattern (structure) of rose-charts, extension lines of roses, the distribution density of elementary linear elements, etc. The portion of the data obtained, particularly, the distribution of lineaments and density distribution of elementary linear elements of the topography (Figures 4 and 5), which exhibits a degree of indentation of the topography, has been used in the present study for the structural construction and further interpretation.

\subsection{Metallogeny}

In the Uchur-Maya basin there have been revealed tantalum, niobium, zirconium, apatite, REE, polymetallic, copper, molybdenum, vanadium, gold and uranium deposits (Figure 2). The deposits and occurrences of gold, vanadium, copper, molybdenum, polymetals and uranium of predominantly stratiform type are localized in the zone of Pre-Calymmian structural-stratigraphic unconformity and in the platform cover [7,23]. In the Neoproterozoic ultrabasic alkali intrusions of the central type, niobium, tantalum with uranium, zirconium and REE deposits have been found. They are clustered in the Arbarastakh, Ingili, Gornoye Ozero, Povorotnyi and Gek massifs [24,25] (Tables 1 and 2; Figures 4 and 5).

Several types of ore-bearing rocks have been discovered including carbonatites, pyroxene-apatite-phlogopitemagnetite-calcite metasomatites and intensely albitized rocks [24]. The complex of minerals includes zircon, fluorite, hatchetolite, pyrochlore, baddeleyite, perovskite, betafite, dysanalyte, monazite, zircon, zirconolite, bastnaesite and columbite. The amounts of magnetite $(3 \%$ $5 \%)$, pyrite $(3 \%-5 \%)$, apatite $(2 \%-3 \%)$ and, also, ilmenite, sphen, hematite and other more rare minerals to $1 \%$ content were detected. The niobium content ranges from $0.2 \%$ to $0.5 \%-1.2 \%$ in the ore zones among carbonatites and metasomatites of the first type, the percentage of tantalum is $0.002 \%-0.1 \%$, that of uranium reaches $0.003 \%-0.3 \%$, thorium amounts to $0.005 \%$ $0.03 \%$, strontium content attains $0.7 \%-1 \%$ and the amount of phosphorus exceeds $10 \%$.

The ores were disclosed in albitites for the first time. They were found in the western endo- and exocontact zones of the Arbarastakh intrusion and exhibit higher 
Table 1. Type and location of deposit fields in the UchurMaya area.

\begin{tabular}{|c|c|c|c|c|}
\hline No. & Name of field & $\begin{array}{l}\text { Type of } \\
\text { deposit }\end{array}$ & Longitude, ${ }^{\circ}$ & Latitude, ${ }^{\circ}$ \\
\hline 1 & Adargai & $\mathrm{U}, \mathrm{Ag}, \mathrm{Mo}$ & 133.4 & 56.8 \\
\hline 2 & Algaminskoe & $\mathrm{Zr}, \mathrm{U}$ & 135.5 & 58.8 \\
\hline 3 & Arbarastakh & $\mathrm{U}, \mathrm{Ta}, \mathrm{Nb}$ & 131.5 & 56.9 \\
\hline 4 & Victoria & $\mathrm{Au}$ & 133.0 & 57.4 \\
\hline 5 & Gek & $\mathrm{Ta}, \mathrm{Nb}$ & 137.3 & 60.7 \\
\hline 6 & Ingili & $\mathrm{Ta}, \mathrm{Nb}, \mathrm{U}$ & 135.3 & 58.6 \\
\hline 7 & $\begin{array}{c}\text { Komsomol'skay } \\
\text { a deposit }\end{array}$ & $\mathrm{Au}$ & 131.8 & 57.7 \\
\hline 8 & Konder & $\mathrm{Pt}$ & 134.7 & 57.7 \\
\hline 9 & Krutoe & $\mathrm{Au}$ & 132.3 & 57.7 \\
\hline 10 & Kun-Man'e & $\mathrm{Ni}, \mathrm{Co}, \mathrm{Pt}$ & 137.5 & 56.5 \\
\hline 11 & Malokomuyskoe & $\mathrm{Cu}, \mathrm{Pb}$ & 137.5 & 57.5 \\
\hline 12 & Baby & $\mathrm{Au}$ & 137.2 & 59.0 \\
\hline 13 & Pereval'noe & $\mathrm{Pb}, \mathrm{Zn}$ & 136.5 & 60.2 \\
\hline 14 & Povorotnyi & $\mathrm{Ta}, \mathrm{Nb}$ & 137.3 & 60.5 \\
\hline 15 & Ryabinovoye & $\mathrm{Au}$ & 133.3 & 57.4 \\
\hline 16 & Sardana & $\mathrm{Pb}, \mathrm{Zn}$ & 136.4 & 60.1 \\
\hline 17 & Tas-Yuryakh & $\mathrm{Au}$ & 137.3 & 58.8 \\
\hline 18 & Uruy & $\mathrm{Pb}, \mathrm{Zn}$ & 136.38 & 59.9 \\
\hline
\end{tabular}

Note: The field numbers in the table correspond to the numbers in Figures 4 and 5.

uranium (to $0.28 \%$ ), niobium (to $2.5 \%$ ) and tantalum (to $0.12 \%$ ) contents as compared to the ores associated with pyroxene-apatite-phlogopite-magnetite-calcite metasomatites and carbonatites.

In Ediacaran rocks the stratiform deposits of zirconium, polymetals, gold and REE of cerium group were detected. The age of mineralization was not determined. $\mathrm{Pb}$ isotopic age determinations yield the Neoproterozoic to Early Paleozoic age range of the ore mineralization.

In the Mesozoic, intense volcanism and intrusive magmatism took place in the Uchur-Maya depression thus forming the Ket-Kap volcano-plutonic gold-bearing zone. This zone is notable for the mixed set of the morphological types of ores (stockworks, stratiform lodes in silicitolites and argillizite-sericite metasomatites).

The formational types of gold mineralization are as follows: gold-sulfide-scarn, vein gold-quartz, gold-quartzhydromicaceous and gold ore in Ediacaran silicitolites (jasperoids). Here, not less than ten predominantly small gold ore deposits have been prospected. High gold pro-
Table 2. Type and location of ore occurrences in the UchurMaya area.

\begin{tabular}{|c|c|c|c|}
\hline No. & $\begin{array}{c}\text { Type of ore occurrences } \\
\text { (name) }\end{array}$ & Longitude, ${ }^{\circ}$ & Latitude, ${ }^{\circ}$ \\
\hline 1 & U (Angor) & 138.0 & 58.7 \\
\hline 2 & $\mathrm{Au}, \mathrm{U}$ (Beglyanka) & 132.6 & 57.2 \\
\hline 3 & Ni, Ta (Gornoye Ozero) & 137.0 & 59.9 \\
\hline 4 & $\mathrm{Au}, \mathrm{V}$ (Konkuli) & 132.9 & 56.8 \\
\hline 5 & $\mathrm{Au}(\mathrm{Oigu})$ & 131.2 & 56.8 \\
\hline 6 & U (Pravougdanskoe) & 133.0 & 56.8 \\
\hline 7 & U (Troika) & 131.9 & 57.2 \\
\hline 8 & U (Ugdan) & 133.1 & 56.7 \\
\hline 9 & $\mathrm{Ce}, \mathrm{Nb}$ (Khamninsk) & 136.3 & 59.7 \\
\hline 10 & U (Khangas) & 133.2 & 56.8 \\
\hline 11 & $\mathrm{Au}$ & 132.8 & 57.0 \\
\hline 12 & $\mathrm{Au}$ & 132.5 & 56.6 \\
\hline 13 & $\mathrm{Au}$ & 132.5 & 56.6 \\
\hline 14 & $\mathrm{Au}$ & 132.3 & 57.5 \\
\hline 15 & $\mathrm{Au}$ & 132.7 & 57.4 \\
\hline 16 & $\mathrm{Au}$ & 133.4 & 57.2 \\
\hline 17 & $\mathrm{Au}$ & 133.9 & 57.0 \\
\hline 18 & $\mathrm{Au}$ & 133.2 & 57.1 \\
\hline 19 & $\mathrm{Au}$ & 133.0 & 57.1 \\
\hline 20 & $\mathrm{Au}$ & 133.2 & 57.0 \\
\hline 21 & $\mathrm{Au}$ & 136.7 & 56.8 \\
\hline 22 & $\mathrm{Au}$ & 136.5 & 56.7 \\
\hline 23 & $\mathrm{Au}$ & 135.8 & 56.2 \\
\hline 24 & $\mathrm{Au}$ & 132.0 & 56.1 \\
\hline 25 & $\mathrm{Au}$ & 137.7 & 62.1 \\
\hline 26 & $\mathrm{Au}$ & 137.9 & 62.2 \\
\hline 27 & $\mathrm{Au}$ & 137.5 & 62.4 \\
\hline 28 & $\mathrm{Au}$ & 137.8 & 62.5 \\
\hline 29 & $\mathrm{Au}$ & 137.8 & 62.4 \\
\hline 30 & $\mathrm{Au}$ & 137.6 & 61.9 \\
\hline 31 & $\mathrm{Au}$ & 137.5 & 61.9 \\
\hline 32 & $\mathrm{Au}$ & 137.6 & 61.8 \\
\hline 33 & $\mathrm{Au}$ & 137.6 & 61.7 \\
\hline 34 & $\mathrm{Au}$ & 137.6 & 61.1 \\
\hline 35 & $\mathrm{Au}$ & 137.8 & 61.2 \\
\hline 36 & $\mathrm{Cu}$ & 131.5 & 58.5 \\
\hline 37 & $\mathrm{~Pb}, \mathrm{Zn}$ & 136.8 & 59.9 \\
\hline 38 & $\mathrm{~Pb}, \mathrm{Zn}$ & 136.8 & 60.0 \\
\hline 39 & $\mathrm{~Pb}, \mathrm{Zn}$ & 136.7 & 60.1 \\
\hline 40 & $\mathrm{~Pb}, \mathrm{Zn}$ & 136.9 & 60.1 \\
\hline
\end{tabular}

Note: The numbers of ore occurrences in the table correspond to the numbers in Figures $\mathbf{4}$ and $\mathbf{5}$. 


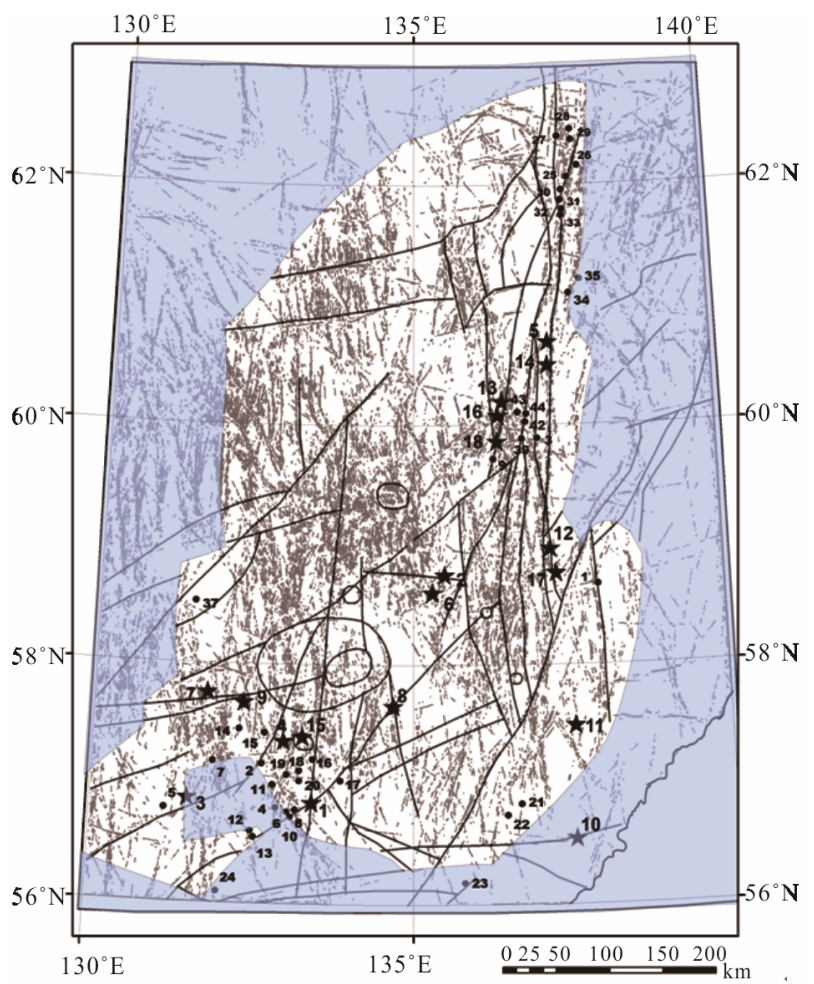

Figure 4. Sketch-map of lineament distribution for the Uchur-Maya basin from processing results using programs "Modulus of gradient of the topography" [1,2], "WinLessa" [3] and locations of major ore deposits and occurrences. Stars show deposits, circles indicate occurrences; numbers before symbols correspond to the numbers given in Tables 1 and 2.

duction capacity of this structure is predetermined by specific conditions of its formation. The majority of gold-ore objects of the Ket-Kap zone are closely associated with massifs of small sub-alkali and alkali intrusive rocks of the Ket-Kap complex, but there are objects where this association is not so obvious. The exploration prospects for the major stratiform "Carlin"-type deposits are associated with silicitolites in the Ediacaran Ust'-Yudoma Suite.

\section{Results}

For all the diversity of metallic minerals and their widespread distribution in the Uchur-Maya depression area, clearly displayed lithological and structural regularities of their localization are observed.

In order to reveal the relationship of ore occurrences of the Uchur-Maya depression with fault tectonics, there have been compiled and interpreted the map of MGR of the digital elevation model for the study area and those of the distribution of lineaments and density distribution of elementary linear elements (Figures 4 and 5).

All the data obtained were integrated into the ArcGis 9.3 Project, where the linear fault network layer based on manual interpretation of the digital elevation model

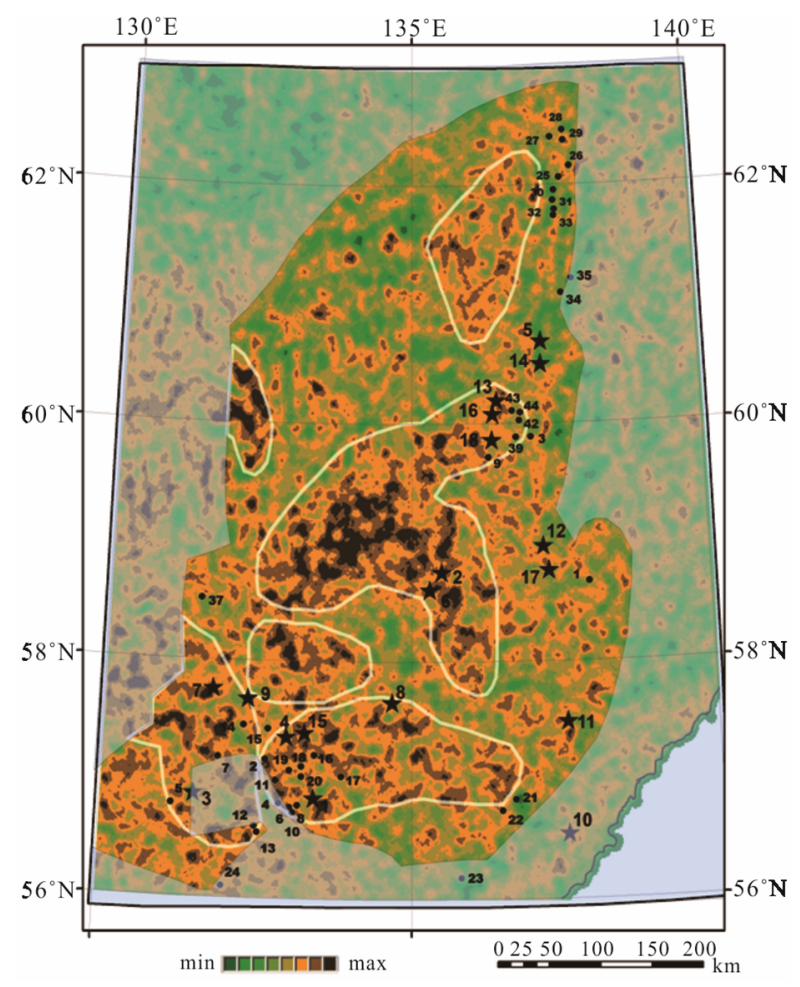

Figure 5. Scheme of density distribution of elementary linear elements of the Uchur-Maya basin from processing results using programs "Modulus of gradient of the topography" $[1,2]$, "WinLessa" [3] and locations of major ore deposits and occurrences. Light-colored lines bound the areas with the maximum density of elementary linear elements.

processed by MGR and the layer of known deposits and occurrences of rare, nonferrous and radioactive metals have also been complemented.

The analysis of the map of visual interpretation (Figure 2) has shown distinctions in the eastern and western parts of the depression either in terms of development of differently oriented fault structures or intensity of their manifestation in the area. In the eastern part of the depression, the meridional and submeridional faults are most common. They are dominantly distributed in the Yudoma-Maya trough and, practically, do not overcome its bounds (Figure 4). It has been established a clear association of gold, uranium and polymetallic mineralization with these faults. Besides, they are controlling the bodies of ultrabasic alkali rocks with tantalum-niobium and REE deposits (Gornoye Ozero, Povorotnyi, Gek and Khamninsk). Consequently, one may assume a close relationship of the detected deposits with the meridional and submeridional faults.

In the central and western parts of the depression, the ore objects are localized in the northeastern stripe of 100 $150 \mathrm{~km}$ width and about $400 \mathrm{~km}$ extent bordered by the Uchur-Ust'-Yudoma and Khaikan-Kerpyl deep faults. Within the stripe, the ore mineralization is controlled by 
the submeridional, northeasterly striking, and, more rarely, sublatitudinal tectonic faults.

The dominating role belongs to the northeasterly trending faults with insignificant participation of the submeridional and northwesterly oriented ones. The orecontrolling role of the Khaikan-Kerpyl fault is most clearly displayed. It controls the Konder platinum deposit, the Vasilek and Tomptokan gold deposits, the Adargai anomalous field with complex U, Mo, $\mathrm{Ag}, \mathrm{Ni}, \mathrm{Co}, \mathrm{Cu}$ and As mineralization, the Khangas and Ugdan uranium occurrences and the Amulikan River basin gold occurrences in the area extending for $180 \mathrm{~km}$ from northeast to southwest. The Algaminskoe uranium-zirconium deposit is controlled by the sublatitudinal fault. A significant part of the objects of this stripe is localized in the gentle shearing areas in the zone of Pre-Riphean structuralstratigraphic unconformity and in scarns in exocontact zones of the Mesozoic granitoid intrusions.

In Figure 4, differently oriented linear lineaments, notably meridional, northeastern and northwestern, are distinctly displayed. The meridional and submeridional faults are mostly widespread, being the most ancient ones due to their control of the formation of meridionally extended Uchur-Maya depression. They are nonuniformly distributed over the depression area. The eastern and western stripes exhibiting the meridional lineament concentration are noticeable. Distinct control of ore deposits and occurrences by the meridional and submeridional lineaments is observed in the Yudoma-Maya trough and the southwestern part of the depression. The proper ore objects are in the majority of cases controlled by junctures of intersection of the meridional lineaments with the northeastern and northwestern ones.

The density distribution map of elementary linear elements of the topography (Figure 5) exhibits the intensity of distribution of differently oriented cracks per unit square. The less disturbed areas are shown in light-grey, whereas the most disturbed ones are colored black. The areas with the maximum density of elementary linear elements are nonuniformly distributed in the UchurMaya depression (Figure 4). A number of such areas are distinguished in the northern part of the Yudoma-Maya trough, in the central part and in the southwest of the depression area. The most clearly manifested relationship of ore occurrences with the maxima of linear element distribution is established for the southern part of the depression (Figure 5). Practically, all presently detected occurrences of gold, uranium and other elements are concentrated within this contoured area. In the central part of the depression, where the most intense area of the linear element distribution is distinguished, the Algaminskoe uranium-zirconium and Ingili uranium-rare metal-REE deposits have been discovered. A sparse set of ore occurrences in this area is explained by extremely poor prospecting of this territory, which we rank promising. As a matter of fact, the same should be noted for the area in the northern part of the Yudoma-Maya trough. This area is worthy of great attention, because polymetallic, gold ore and rare metal deposits have been found to the east and south of it in the trough, in the fields of less intense areas.

\section{Conclusions}

As a result of the studies carried out, it has been established a clearly displayed control of the ore deposits and occurrences by the faults.

1) In the eastern part of the Uchur-Maya depression and in the Yudoma-Maya riftogenic trough, the ore mineralization is controlled by the extended (hundreds of kilometers) meridional tectonic fault zones;

2) In the central and western parts of the depression area, the ore objects are localized in the northeastern stripe of $100-150 \mathrm{~km}$ width and of about $400 \mathrm{~km}$ extent, bordered by the Uchur-Ust'-Yudoma and Khaikan-Kerpyl deep faults. Within the stripe, the ore mineralization is controlled by the submeridional, northeasterly striking, and, more rarely, sublatitudinal tectonic faults;

3) The maxima of the concentration of ore deposits and occurrences are observed in the segments with high density of the meridional lineaments. The relationship of the deposits with the maximum density of linear elements is revealed in the central and southwestern parts of the depression and is practically not exhibited in the Yudoma-Maya trough.

The Uchur-Maya trough is the prospective structure for exploration of gold, uranium, polymetallic, silver, molybdenum, copper, nickel, platinum, rare and REE deposits of unconventional formational types, having no analogs in the Russian Far East area.

\section{Acknowledgements}

The authors are thankful to the anonymous reviewers whose remarks and suggestions contributed to better understanding of the manuscript by the readers. Thanks are also due to N. N. Kovriga, E. Yu. Didenko and O. M. Men'shikova for their assistance in the preparation of the manuscript.

The studies have been supported by the Far Eastern Branch of the Russian Academy of Sciences (RAS) (Program of Satellite Monitoring and Project No. 12-I0-08-004) and the Russian Foundation for Basic Research of the RAS (Projects Nos. 12-05-00088a and 1205-91158).

\section{REFERENCES}

[1] O. V. Rybas and G. Z. Gil'manova, "Application of the Scale-Space Theory for Detection and Analysis of the 
Topography Structures from SRTM Data," Investigation of the Earth from Space, No. 6, 2011, pp. 45-52.

[2] O. V. Rybas, G. Z. Gil'manova and M. V. Goroshko, "Application of Transformed Small-Scale Digital Elevation Models for Detection of Major Crustal Blocks," XIII Russian Conference "Distributed Information and Computational Resources" (DICR'2010), Novosibirsk, 30 November-3 December 2010, p. 28.

http://conf.nsc.ru/dicr2010/ru/reportview/31576

[3] A. Zlatopolsky, "Description of Texture Orientation in Remote Sensing Data Using Computer Program LESSA," Computers \& Geosciences, Vol. 23. No. 1, 1997, pp. 4562. doi:10.1016/S0098-3004(96)00053-2

[4] M. A. Semikhatov and S. N. Serebryakov, "Siberian Hypostratotype of the Riphean," Nedra, Moscow, 1983.

[5] A. K. Khudoley, R. H. Rainbird, R. A. Stern, A. P. Kropachev, L. M. Heaman, A. M. Zanin, V. N. Podkovyrov, V. N. Belova and V. I. Sukhorukov, "Sedimentary Evolution of the Riphean - Vendian Basin of Southeastern Siberia," Precambrian Research, Vol. 111, No. 1-4, 2001, pp. 129-163. doi:10.1016/S0301-9268(01)00159-0

[6] S. A. Pisarevsky and L. M. Natapov, "Siberia and Rodinia," Tectonophysics, Vol. 375, No. 1-4, 2003, pp. 221-245. doi:10.1016/j.tecto.2003.06.001

[7] M. V. Goroshko and V. A. Gur'yanov, "Ore Mineralization Related to the Zone of the Pre-Riphean Structural-Stratigraphic Unconformity and Lower Riphean Platform Cover of the Uchur-Maya Depression, the Southeastern Siberian Platform," Russian Journal of Pacific Geology, Vol. 1, No. 6, 2007, pp. 586-602. doi:10.1134/S1819714007060073

[8] M. V. Goroshko and V. A. Gur'yanov, "Meso-Neoproterozoic Complexes of Southeastern Siberian Platform Cover: Conditions of the Formation and Main Tectonic Features," Geotectonics, No. 2, 2008, pp. 147-163. doi:10.1134/S0016852108020052

[9] A. N. Didenko and M. V. Goroshko, "Uchur-Maya Sedimentary Basin of Southeastern Siberian Craton: Stratigraphy, Geodynamics and Petroleum Potential," Proceedings of the Conference, Novosibirsk, 30 June-2 August 2011, pp. 17-18.

[10] G. V. Ovchinnikova, M. A. Semikhatov, I. M. Vasil'eva, I. M. Gorokhov, O. K. Kaurova, V. N. Podkovyrov and B. $\mathrm{M}$. Gorokhovskii, " $\mathrm{Pb}-\mathrm{Pb}$ Age of Limestones of the Middle Riphean Malgina Formation, the Uchur-Maya Region of East Siberia," Stratigraphy and Geological Correlation, Vol. 9, No. 6, 2001, pp. 527-540.

[11] M. A. Semikhatov, "Refinement of the Estimates of the Isotopic Age of the Lower Boundary of the Upper Riphean, Vendian, Upper Vendian and Cambrian," Additions to the Stratigraphic Code of Russia, St. Petersburg, 2000.

[12] R. H. Rainbird, R. A. Stern, A. K. Khudoley, A. P. Kropachev, L. M. Heaman and V. I. Sukhorukov, "U-Pb Geochronology of Riphean Sandstone and Gabbro from Southeast Siberia and Its Bearing on the Laurentia-Siberia Connection," Earth and Planetary Scientific Letters, Vol. 164, No. 3, 1998, pp. 409-420. doi:10.1016/S0012-821X(98)00222-2
[13] The State of Precambrian and Phanerozoic Stratigraphic Study in Russia, "Objectives for Further Investigations. Resolutions of the Interdepartmental Stratigraphic Committee and Its Standing Commissions," VSEGEI Publishing House, Saint-Petersburg, 2008, 131 p.

[14] V. I. Vinogradov, V. I. Murav'ev, M. I. Bujakaite, D. I. Golovin, V. M. Gorozhanin and A. F. Veis, "Epigenesis of Middle Riphean Rocks in the Bashkir Meganticlinorium, Southern Urals: Timing of Alterations and Geological Implications," Lithology and Mineral Resources, Vol. 35, No. 6, 2000, pp. 571-583. doi:10.1023/A:1026601616053

[15] V. A. Yan-Zhin-Shin, "Tectonics of the Sette-Daban Horst-Anticlinorium," Yakutsk Branch of the Siberian Division of the Academy of Sciences of the USSR, Yakutsk, 1983.

[16] Vendian System, "Historical and Geological and Paleontological Study," In: B. S. Sokolov and M. A. Fedonkin, Eds., Stratigraphy and Geological Processes, Nauka, Moscow, 1985, $237 \mathrm{p}$.

[17] M. A. Semikhatov, G. V. Ovchinnikova, I. M. Gorokhov, A. B. Kuznetsov, O. K. Kaurova and P. Yu. Petrov, "Pb-Pb-Isochronic Age and Sr-Isotopic Characteristic of the Upper Yudoma Carbonate Deposits (Vendian of the Udoma-Maya Trough, Eastern Siberia)," Doklady Akademii Nauk, Vol. 393, No. 1, 2003, pp. 83-87.

[18] A. N. Didenko, V. Yu. Vodovozov, I. K. Kozakov and E. V. Bibikova, "Paleomagnetic and Geochronological Study of Post-Collisional Early Proterozoic Granitoids in the Southern Siberian Platform: Methodological and Geodynamic Aspects," Izvestiya. Physics of the Solid Earth, Vol. 41, No. 2, 2005, pp. 156-172.

[19] K. C. Condie, "Breakup of a Paleoproterozoic Supercontinent," Gondwana Research, Vol. 5, No. 1, 2002, pp. 41-43. doi:10.1016/S1342-937X(05)70886-8

[20] A. P. Witkin, "Scale-Space Filtering," Proceedings 8th International Joint Conference on Artificial Intelligence, Karlsruhe, 1983, pp. 1019-1022.

[21] J. J. Koenderink, "The Structure of Images," Biological Cybernetics, Vol. 50, No. 5, 1984, pp. 363-370. doi:10.1007/BF00336961

[22] J. J. Koenderink and A. J. van Doorn, "Representation of Local Geometry in the Visual System," Biological Cybernetics, Vol. 55, No. 6, 1987, pp. 367-375. doi:10.1007/BF00318371

[23] Y. F. Malyshev and M. V. Goroshko, "Regional Potassic Metasomatism and Metallogeny of Precambrian Structural-Stratigraphic Unconformity Zones (Southeastern Siberian Platform)," Doklady Rossiyskoy Akademii Nauk, Vol. 423, No. 5, 2008, pp. 663-666.

[24] M. V. Goroshko and V. A. Guroyanov, "Conditions of Location of Complex Uranium-Rare Metal Mineralization in the Massifs of Ultrabasic Alkali Rocks, South-Eastern Part of the Siberian Platform," Russian Journal of Pacific Geology, Vol. 23, No. 2, 2004, pp. 76-91.

[25] L. M. Parfenov and M. I. Kuz'min, “Tectonics, Geodynamics and Metallogeny of the Sakha Republic (Yakutia)," Nauka/Interperiodika, Moscow, 2001.

[26] L. J. Pesonen, S. A. Elming, S. Mertanen, S. Pisarevsky, 
M. S. D’Agrella, J. G. Meert, P. W. Schmidt, N. Abrahamsen and G. Bylund, "Palaeomagnetic Configuration of Continents during the Proterozoic," Tectonophysics, Vol. 375, No. 1-4, 2003, pp. 289-324.

doi:10.1016/S0040-1951(03)00343-3

[27] Z. X. Li, S. V. Bogdanova, A. S. Collins, A. Davidson, B. De Waele, R. E. Ernst, I. C. W. Fitzsimons, R. A. Fuck, D. P. Gladkochub, J. Jacobs, K. E. Karlstrom, S. Lu, L. M. Natapov, V. Pease, S. A. Pisarevsky, K. Thrane and V. Vernikovsky, "Assembly, Configuration, and Break-Up History of Rodinia: A Synthesis," Precambrian Research, Vol. 160, No. 1-2, 2008, pp. 179-210. doi:10.1016/j.precamres.2007.04.021
[28] R. E. Ernst, K. L. Buchan, M. A. Hamilton, A. V. Okrugin and $\mathrm{M}$. D. Tomshin, "Integrated Paleomagnetism and U-Pb Geochronology of Mafic Dikes of the Eastern Anabar Shield Region, Siberia: Implications for Mesoproterozoic Paleolatitude of Siberia and Comparison with Laurentia," The Journal of Geology, Vol. 108, No. 3, 2000, pp. 383-401.

[29] T. N. Kheraskova, V. A. Bush, A. N. Didenko and S. G. Samygin, "Breakup of Rodinia and Early Stages of Evolution of the Paleoasian Ocean," Geotectonics, Vol. 44, No. 1, 2010, pp. 1-24. 